\title{
THEORIES, STYLES AND STRATEGIES OF LEARNING IN E-LEARNING
}

Milan KLEMENT*, Univerzita Palackého v Olomouci

Přijato: 10. 3. 2016 / Akceptováno: 31. 5. 2016

Typ článku: Teoretická studie

DOI: $10.5507 /$ jtie.2016.014

Abstract: Information and communication technologies currently provide many incentives for the development of the educational process not only at the application, but also at the theoretical level. The very process of integrating these technologies into teaching, sometimes called simply the electronic learning (e-learning), however, was no one-off and had stemmed from several different theories of learning, determining the different levels and methods of use. The submitted article presents connections between the particular theories of learning and the possibilities of support from information and communication technologies, with particular focus on the issues of distance education, implemented by e-learning.

Key words: theory of learning, individualized learning, distance learning, computer technology, information and communication technologies, e-learning.

\section{TEORIE, STYLY A STRATEGIE UČENÍ(SE) V E-LEARNINGU}

Resumé: Informačni a komunikačni technologie v současné době poskytuji mnoho podnětu pro rozvoj edukačního procesu, a to nejen v rovině aplikační, ale $i$ v rovinè teoretické. Samotný proces začleňování těchto technologií do výuky, nazývaný někdy zjednodušeně elektronickým učením (e-Learning), ale nebyl jednorázový a vycházel také z několika rưzných teorii učení, které determinovaly jednotlivé úrovně a způsoby využití. Předložená stat’ představuje souvislosti mezi jednotlivými teoriemi učení a možnostmi podpory ze strany informačních a komunikačních technologii,, se zvláštním zaměrením na problematiku distančního vzdélávání realizovaného formou e-learningu.

Klíčová slova: teorie učení, individualizované učení, distanční vzdělávání, výpočetní technika, informační a komunikační technologie, e-learning.

*Autor pro korespondenci: milan.klement@upol.cz 


\section{1 Úvod}

Pojmy distanční vzdělávání či vzdělávání realizované formou e-learningu (často označovaný zkráceně jako e-learning) jsou v současnosti velmi frekventovanými. V našem geografickém prostoru bývají spojovány především s realizací vzdělávání v rámci terciálního stupně vzdělávacího systému a přesahem do celoživotního vzdělávání, ale objevují se již snahy o rozšiření tohoto způsobu vzdělávání, především v oblasti využití e-learningu, na nižší stupně vzdělávací soustavy. Tyto snahy vycházejí z konstruktivistického paradigmatu vzdělávání, které jsou založeny na předpokladu, že každý učební proces je hluboce individuální a že znalost je tvořena vlastní zkušeností $\mathrm{a}$ interpretací světa. Role učitele a žáka se $\mathrm{v}$ takto pojatém procesu radikálně mění a tomuto pojetí tedy musí být i podřizeny podmínky a prostředky za jakých je vzdělávání realizováno.

E-learning se tak stal perspektivně rozvíjející se oblastí, která je kontinuálně, systematicky a intenzivně řešena na mezinárodní i tuzemské úrovni - lze především uvést práce od autorů: S. B. Eom \& J. B. Arbaugh, (2011), R. C. Clark \& R. E. Mayer (2011), Y. J. Joo, K. Y. Lim \& E. K. Kim (2011), A. Mauthe \& P. Thomas (2004), J. Anderson, \& R. McCormick (2005), S. Bennett, K. Maton \& L. Kervin (2008), S. Kluge \& L. Riley (2008), M. F. Paulsen (2003), D. S. Smith \& J. BCaruso (2010), A. Bates \& G. Poole (2003), R. Ramanau, A. Hosein, \& Ch. Jones (2010), J. Zounek (2009), I. Šimonová, (2010) aj.

Pojem e-learning, prŕpadně i jeho kvalita, je ale často rozporuplně vnímán a definován (Eger, 2004). Hlavní př́činou je odlišná terminologie, která je do značené míry ovlivněna jazykovými vlivy a růzností použitých př́stupů $i$ technologií. $\mathrm{V}$ transatlantickém prostoru se pro aktivity spojené s podporou výuky pomocí ICT (e-support) se používá namísto pojmu e-learning (Lowenthal \& Wilson, 2009) relativně ustálených pojmů Computer-Based Training (CBT), Internet-Based Training (IBT) nebo Web-Based Training (WBT) (Zounek, 2009). V evropském prostoru existuje konsenzus o použití jednotného pojmu e-learning, který je dle informačního e-learningového portálu pro Evropu Elearningeuropa.info chápán jako „aplikace nových multimediálních technologii a Internetu do vzdélávání za účelem zvýšení jeho kvality posílením prístupu ke zdrojům, službám, $k$ výměně informací a ke spolupráci “ (Šimonová, 2010).

E-learning $\mathrm{v}$ tomto pojetí zahrnuje nejen řadu nástrojů, které slouží pro prezentaci, transfer vzdělávacího obsahu a řízení studia, ale také celé spektrum komunikačních kanálů. Využití nástrojů umožňuje Learning Management System (LMS), který je nezbytným předpokladem pro skutečně efektivní proces vzdělávání $\mathrm{s}$ využitím e-learningu. LMS tedy reprezentuje virtuální „učebni““ prostředí, ve kterém se nacházejí multimediální studijní materiály, zkušební testy, studijní instrukce, cvičební plány nebo diskusní fóra (Klement, 2012). Základními nástroji realizace e-learningového vzdělávání jsou tak mimo LMS také vhodně strukturované a didakticky uzpůsobené vzdělávací materiály, zkráceně označované jako studijní opory nebo také jako elektronické studijní materiály (srov. Šedá, 2010; Kopecký, 2006).

\section{Použité metody}

Zvolená metodologie vychází z analýzy stávajících pedagogických teorií zaměřených na problematiku využivání informačních a komunikačních technologií $\mathrm{v}$ rámci distančního vzdělávání realizovaného formou e-learningu a rozpracování uvedené formy 
vzdělávání na současnou úroveň. Syntetizací získaných teoretických poznatků a popisu aktuální praxe jsme získali předpoklady pro aplikaci těchto teorií v reflexi současných trendů oblasti distančního vzdělávání realizovaného formou e-learningu. Na základě provedené analýzy bylo možné, mimo jiné, rozššríit obecné principy distančního vzdělávání o další nutný princip interaktivity a upresnit výklad principu multimediality, aby byly $\mathrm{v}$ souladu se stávající úrovní poznatků $\mathrm{v}$ oblasti pedagogiky, především pedagogickým konstruktivismem. $\mathrm{V}$ této oblasti jsme tedy pomocí komparační analýzy vymezili význam teorií učení pro různé stupně vývoje distančního vzdělávání a vliv rozvoje informačních a komunikačních technologií na způsob uplatňování těchto pedagogických teorií. Syntézou získaných teoretických poznatků vznikla aktualizace teorie distančního vzdělávání. Její změna spočívá především v úpravě a rozpracování základních principů distančního vzdělávání, přičemž v podmínkách realizace formou e-learningu je nutné vymezit nové chápání pojmu multimediality a interaktivity.

$\mathrm{Na}$ základě analýzy behaviorálních, neobehaviorálních, kognitivistických a konstruktivistických psychologických teorií společně $\mathrm{s}$ novými př́stupy $\mathrm{k}$ využití výpočetní techniky budou následně na základě syntézy těchto poznatků vytvořena obecněji platná východiska odrážející nejnovější možnosti informačních a komunikačních technologií a způsob jejich zapojení do distančního vzdělávání realizovaného formou e-learningu, což je také předmětem dalšího sdělení uvedeného v následujících kapitolách předložené stati.

\section{Teorie učení a e-learning}

E-learning jakožto progresivně se rozvíjející forma vzdělávání se tak dostala do popředí zájmu fillozofů, pedagogů či didaktiků jako jeden z možných prostředků pro dosažení cílů konstruktivistické teorie učení. Z hlediska uplatňování pedagogickopsychologických př́istupů ke vzdělávání s využitím výpočetní techniky a počítačových sítí e-learning postupně odrážel tři teorie učení, které měly a mají zásadní vliv na konstrukci vzdělávacího obsahu v podmínkách jeho realizace:

- Behaviorismus (neobehaviorismus) - studijní materiály vycházející z tohoto psychologického směru čekají vždy na reakci studenta. Jejich struktura vychází $\mathrm{z}$ předem připravené a předepsané struktury podnětů - úkolů, které jsou předkládány učícímu se subjektu, po nichž následuje diagnostika kvality (chování) odpovědi studenta a jejího zpevnění - omezení (ne)správnosti (Hunt, 2000).

- Kognitivní psychologie - vycházející ze základní teze, že modifikaci lidského chování determinují vnitřní faktory, zvláště pak „vědění - knowledge“. Hlavní důraz je kladen na znalosti jak deklarativní povahy (soubory jednotlivých poznatků), tak procesní (vybavenost postupy při jejich získávání a zpracování) (Plháková, 2006). V podmínkách e-learningu je hlavní dưraz kladen na materiály, které obsahují celou škálu podnětů k dosahování kognitivních cílů vzdělávání a to za využití široké palety informačních zdrojů.

- $\quad$ Konstruktivismus - chápe učení jako proces, ve kterém student konstruuje své znalosti osobitým způsobem (bez předem stanoveného předpisu) v návaznosti na předchozí zkušenosti a vysoce aktivním vyhledáváním podnětů a potřebných informací v široce „otevřeném informačním prostoru“ (pomocí tzv. otevřených technologií), ve kterém může bez omezení vytvářet originální řešení (Piaget, 
1999). V podmínkách e-learningu je uplatnění této teorie vyjádřeno potřebou budování podnětně bohatých a aktivizujících „učebních“ prostředí pro individuální i skupinové formy studia, často charakterizované termínem „hypermedia learning enviroments“(Petty, 1996).

Pro názornost je $\mathrm{v}$ tabulce 1 uvedeno porovnání jednotlivých teorií učení tak, jak na sebe historicky navazovaly. $V$ tabulce jsou popsány pouze ty nejdůležitější atributy každé z teorií a je také zdůrazněno uplatnění dané teorie v podmínkách e-learningu, který stejně jako ostatní formy a metody vzdělávání, prošel výrazným rozvojem. Tento rozvoj byl v př́padě e-learningu stimulován dvěma faktory. $\mathrm{V}$ uvedené tabulce jsou oba tyto faktory zachyceny současně, což může čtenáři předložené stati pomoci $\mathrm{s}$ orientací v problematice vztahů mezi teoriemi učení a e-learningem.

\begin{tabular}{|c|c|c|c|}
\hline $\begin{array}{l}\text { Psychologický } \\
\text { směr }\end{array}$ & $\overline{\text { Behaviorismus }}$ & $\begin{array}{l}\text { Kognitivní } \\
\text { psychologie }\end{array}$ & Konstruktivismus \\
\hline Teorie učení & Programované učení & Kognitivní teorie & Konstruktivní učení \\
\hline $\begin{array}{c}\text { Princip } \\
\text { procesu učení }\end{array}$ & $\begin{array}{l}\text { Podnět (S-stimulus)- } \\
\text { Reakce (R-reaction)- } \\
\text { Zpevnění (Rf- } \\
\text { reinforcement). }\end{array}$ & $\begin{array}{l}\text { Strukturování } \\
\text { a organizování informací. } \\
\text { Domény kognitivní, } \\
\text { psychomotorická } \\
\text { a postojová. }\end{array}$ & $\begin{array}{l}\text { Učení vytvářením } \\
\text { a aktualizací vzorců } \\
\text { (asimilací } \\
\text { a akomodací). }\end{array}$ \\
\hline $\begin{array}{l}\text { Výsledek } \\
\text { učení }\end{array}$ & $\begin{array}{l}\text { Změna chování } \\
\text { automatizací. }\end{array}$ & $\begin{array}{l}\text { Změna chování } \\
\text { myšlenkovým procesem. }\end{array}$ & $\begin{array}{l}\text { Změna zkušeností } \\
\text { a schémat. }\end{array}$ \\
\hline Postup učení & $\begin{array}{l}\text { Učení nastává, je-li } \\
\text { vyvoláno otázkou } \\
\text { vedoucí k aktivní } \\
\text { odpovědi, je-li } \\
\text { uskutečňováno vlastním } \\
\text { tempem v malých } \\
\text { krocích, je-li zpevňováno } \\
\text { znalostí správné } \\
\text { odpovědi a zpevnění je } \\
\text { řízeno programem. }\end{array}$ & $\begin{array}{l}\text { Učení nastává } \\
\text { zpracováním informací } \\
\text { prostřednictvím } \\
\text { procesorů a uložením, } \\
\text { strukturováním } \\
\text { a organizováním } \\
\text { v paměti. Devět událostí } \\
\text { učení. Rozdělení učiva } \\
\text { do malých krokủ. }\end{array}$ & $\begin{array}{l}\text { Učení nastává osobní } \\
\text { zkušeností žáka, } \\
\text { zařazováním znalostí } \\
\text { do kontextu, jejich } \\
\text { asimilací do existujících } \\
\text { kontextů, resp. } \\
\text { vytvářením nových } \\
\text { souvislostí a vzorců. Žák } \\
\text { učení kontroluje a řídí. }\end{array}$ \\
\hline Metody & $\begin{array}{l}\text { Stanovení cílů, otázka, } \\
\text { problém, aktivní } \\
\text { odpověd', postupná } \\
\text { progrese, iterace } \\
\text { ke správné odpovědi, } \\
\text { drilování, procvičování, } \\
\text { asociace, zřetězení, } \\
\text { zobecňování, měření } \\
\text { výkonu podle cílů. }\end{array}$ & $\begin{array}{l}\text { Stanovení cílů, } \\
\text { vysvětlování, } \\
\text { demonstrace, ilustrování, } \\
\text { klasifikace, } \\
\text { strukturování, } \\
\text { organizování, příklady, } \\
\text { algoritmické řešení } \\
\text { problémů, analogie, } \\
\text { porozumění, analýza, } \\
\text { syntéza, aplikace, } \\
\text { hodnocení. }\end{array}$ & $\begin{array}{l}\text { Modelování, simulace, } \\
\text { heuristické řešení } \\
\text { problémů, objektové } \\
\text { učení, situační učení, } \\
\text { autentické učení, } \\
\text { kontextualizace, } \\
\text { hypertexty, větvení, } \\
\text { sociální přístupy, } \\
\text { objevování, zkoumání, } \\
\text { vedení, kolaborativní } \\
\text { konstrukce. }\end{array}$ \\
\hline $\begin{array}{c}\text { Forma } \\
\text { realizace }\end{array}$ & Korespondenční & Multimediální & Hypermediální \\
\hline $\begin{array}{c}\text { Technologie } \\
\text { prezentace, } \\
\text { komunikace } \\
\text { a řízení. }\end{array}$ & $\begin{array}{l}\text { Distanční vzdělávání } \\
\text { realizované } \\
\text { korespondenční formou } \\
\text { s využitím poštovního } \\
\text { listovního styku, } \\
\text { telefonních rozhovorů či } \\
\text { sdělení zasílaných faxy. }\end{array}$ & $\begin{array}{l}\text { E-learning postavený } \\
\text { na využití více druhủ } \\
\text { přenosových médií } \\
\text { (masmédií), rozhlas, } \\
\text { televize, počítačové } \\
\text { programy, multimediální } \\
\text { audio a video záznamy, }\end{array}$ & $\begin{array}{l}\text { E-learning postavený } \\
\text { na plně počítačové bázi. } \\
\text { Počítač či výpočetní } \\
\text { systém je promítnut } \\
\text { do každé činnosti } \\
\text { studujícího i tutora. Je } \\
\text { realizován za podpory }\end{array}$ \\
\hline
\end{tabular}




\begin{tabular}{|c|c|c|c|}
\hline & & CD a DVD ROM. & $\begin{array}{l}\text { moderních informačních } \\
\text { a komunikačních } \\
\text { prostředků. }\end{array}$ \\
\hline $\begin{array}{l}\text { Převažující } \\
\text { typ studijních } \\
\text { materiálů. }\end{array}$ & $\begin{array}{l}\text { Tištěné, koncipované } \\
\text { na základě linearity } \\
\text { textu, využití pouze } \\
\text { statické obrazové } \\
\text { informace. }\end{array}$ & $\begin{array}{l}\text { V off-line podobě, } \\
\text { koncipované na základě } \\
\text { větvení, doplněné } \\
\text { o různé nosiče } \\
\text { vzdělávacího obsahu } \\
\text { postaveného na využití } \\
\text { elektronických médií } \\
\text { a výpočetní techniky. }\end{array}$ & $\begin{array}{l}\text { V on-line podobě, plně } \\
\text { elektronické, využívající } \\
\text { principu hypertextu, } \\
\text { zakomponované do plně } \\
\text { digitalizovaného } \\
\text { učebního prostředí, } \\
\text { v podobě sofistikovaného } \\
\text { LMS systému. }\end{array}$ \\
\hline
\end{tabular}

Tab. č. 1: Porovnáni jednotlivých teorií učeni v souvislosti s distančním vzděláváním a jeho vývojem.

Uvedené teorie učení měly vliv na vývoj e-learningu od individualizovaného vzdělávání, přes distanční vzdělávání až po jeho moderní podoby (m-learning, MOOC apod.). Mimo uvedené teorie učení měly na celý proces vývoje e-learningu zásadní vliv technologie a jejich rozvoj.

Informační a komunikační technologie, v důsledku jejich rozšíření do všech oblastí života, ovlivnily také samotné př́ijemce vzdělávání - žáky. Představa přirozeného využívání informačních a komunikačních technologií, tedy moderních sociálních sítí a otevřených informačních zdrojů, dnešní generací žáků a studentů se postupem času začal vnímat jako fakt, který se opírá o dva hlavní argumenty. První z nich vychází z faktu, že dnešní děti a studenti manipulují a ovládají výpočetní techniku se zarážející samožrejmostí. Druhý argument vychází ze statistik uživání ICT podle věku, které ukazují, že na rozdíl od starších generací využívají skoro všechny děti Internet a počítač (Lupač, 2011). Na těchto dvou argumentech postavil v roce 1998 americký autor Don Tapscott (1998, s. 22-27) své úvahy, kdy označil mocenský model rodiny za narušený, nebot' jsou to děti, které dnes učí rodiče orientovat se v digitálním prostředí. $\mathrm{K}$ jeho označení N-GEN a digitální generace se brzy přidali další: digitální domorodci (Prensky, 2001, s. 5), homo-zappiens (Veen \& Vrakking, 2006, s. 38), digitálně narození (Palfrey \& Glasser, 2008) a další. „Digitální domorodci jsou zvykli přijímat informace velmi rychle. Rádi dělají více činností zároveñ (multitasking). Uprednostňují zpracování obrazového materiálu dř́ve než textu. Preferuji náhodný př́stup $k$ informacím (hypertext) a nejlépe se jim pracuje v sitovém prostředí (on-line). Očekávaji okamžitou pochvalu a časté oceňování vlastní tvorby" (Prensky, 2001, s. 6). Prenskyho a Tapscottovy představy se staly velmi vlivnými a pokusilo je $\mathrm{v}$ postupu času podpořit či vyvrátit několik výzkumníků a to se stř́davým úspěchem (Bennett, Maton \& Kervin, 2008, 12-31).

I když se doposud výše uvedenou kategorizaci žáků a studentů nepodařilo jednoznačně prokázat, (Brown, 2008, s. 66) i sám autor této kategorizace ve svých pozdějších pracích tento koncept přehodnotil a začal použivat spíše pojem „digitální moudrost" (digital wisdom) (Prensky, 2009, s. 7-11), podnítili tyto úvahy rozvoj nového konceptu teorie učení postaveného na využití možností moderních informačních a komunikačních technologií, který byl označen jako konektivismus (Downes, 2012, s. 45). 


\section{Teorie učení vycházející z e-learningu - konektivismus}

Koncept konektivismu (ang. connectivism) "jakožto teorie učení v digitálním věku" byl poprvé představen G. Siemensem a S. Dowensem na základě jejich analýzy nedostatků dosavadních teorií učení vycházejících $\mathrm{z}$ behaviorismu, kognitivizmu a konstruktivizmu (Siemens, 2005, s. 3). Je tedy postaven na sociokognitivní teorii vzdělávání a zohledňuje skutečnost, že žák konstruuje systém vědění (např. kognitivní mapy vědění apod.) v podmínkách svého sociálního prostředí (např. Vygotskij, 1962). Konektivismus tak pohlíží na vzdělávání jako na proces, který se odehrává v prostředí počítačové sítě přesahující rámec jednotlivce. Konektivismus, jakožto aplikovaná teorie konstruktivismu, tedy vychází z přesvědčení, že ,každý učebni proces je hluboce individuální a že znalost je tvořena (konstruována) vlastni zkušeností a interpretací světa " (Piaget, 1955). Role žáka se tak mění - z pasivní nádoby, kterou je nutné naplnit vědomostmi, na aktivního účastníka vzdělávacího procesu, který si sám utváŕí znalosti a realitu kolem sebe (Zounek, Sudický, 2012, s. 45). Proto konektivismus chápe porozumění žáka jako závislé na vlastnostech sítě a způsobu tam prezentovaných informací, v níž každý člen obhospodařuje jen určitou část znalostí (Montcon, 2007, s. 8). Podobně tak i výuka založená na principech konstruktivismu situuje žáka do středu celého procesu a svým pojetím je činnostní (na rozdíl od pasivního instruktivismu). S tím se samozřejmě mění i role učitele $-\mathrm{z}$ autoritativního zdroje poznání na pomocníka (facilitátora), který podporuje žáky ve vlastním vzdělávání (Tracey, 2009, s 18-19).

Klíčovým aspektem takto koncipované výuky je vytváření a udržování propojení na síti, která $\mathrm{v}$ podstatě rozšiřují znalostní základnu jedince nad rámec jeho vlastní kapacity. Dalším aspektem je fakt, že objem informací, se kterými se žák (ve smyslu intencionálního i neintencionálního vzdělávání) setkává, je př́liš velký, než aby mohl být internalizován učením nebo zkušeností, a zároveň se příliš rychle mění a zastarává (Downes, 2012, s. 214 - 217). Siemens uvádí, že sítová spojení, která nám umožňují další učení a rozvoj, jsou důležitější než aktuální stav znalostí (Siemens, 2005, s. 4). Nezbytnou kompetencí současných žáků a studentů musí však zároveň být umění organizace vlastních učebních sítí, jež v budoucnu umožní pokračující sebevzdělávání.

V souvislosti s publikačními a výzkumnými aktivitami souvisejícími s problematikou využití a použití informačních a komunikačních technologií ve vzdělávání na základě implementace konceptu konektivistické teorie učení, je možné vypozorovat dva převažující myšlenkové proudy.

První, historicky starší, myšlenkový proud se zaměřuje na problematiku využití učebních sítí (learning networks) ve vzdělávání. Řešena jsou zde především témata související s e-learningem v tzv. „užším pojetí“, tedy z pohledu realizace vzdělávání distanční formou s minimální prezenční účasti vzdělávaného ve výuce. Existuje tedy celá řada studií, teoretických i empirických studií, které se zabývají touto problematikou, např́klad: J. Zounek (2009), R. C. Clark \& R. E. Mayer (2011), M. F. Paulsen, (2003), A. Barešová (2003), L. Eger (2004), K. Kopecký (2006), J. Průcha \& J. Mika (2000) a další.

Druhý myšlenkový proud se zaměřuje na problematiku související s e-learningem v tzv. „Širším pojetí“, kdy do tohoto okruhu spadají nová témata zabývající se např́klad možnostmi využití MOOC (Massive Open Online Course) a sociálních sítí (Web 2.0) ve vzdělávání. Oproti prvnímu myšlenkovému proudu jsou zde řešeny obecnější otázky a principy, zabývající se nejen možnosti distribuce vzdělávacího obsahu a komunikace 
pomocí počítačových sítí, ale také vhodnou strukturací výukových materiálů a vlivu komunikace na celý proces. Opět se v této oblasti setkáme $\mathrm{s}$ celou řadou autorů zabývajících se tímto problémem, např́iklad: S. Matt \& L. Fernandez (2013), Ch. Parr (2012), R. Kop (2011), T. Iiyoshi \& M. S. Vijay (2008), Y. Li \& S. Powell (2013), J. Zounek \& P. Sudický (2012) a další.

\section{5 „Konektivistický“ e-learning a jeho nástroje}

Pro budování vlastních učebních sítí edukanta a pro internalizaci základní vědomostní struktury, včetně dalšího prohloubení odbornosti se tedy začínají uplatňovat konstruktivistické metody, při kterých se zapojuje proces aktivního sociálního učení (Oblinger \& Oblinger, 2005). Ve virtuálním prostředí slouží k vlastní konstrukci znalostí některé specifické postupy a nástroje úzce svázané s moderními informačními a komunikačními technologiemi (Tracey, 2009):

- diskusní fóra - pokládání otázek, ujasňování kontextu, sdílení vědomostí,

- wiki moduly a nelineární znalostní banky - sociální konstrukce znalostí,

- vyhledávací funkce - samostatná organizace dalšího bádání.

Vyšší úroveň, pokud jde o úroveň znalostí a dovedností, představují nástroje a aktivity vycházející z teorie konektivismu, které zavádějí nutnost napojení na relevantní zdroje informací $\mathrm{v}$ současném exponenciálním nárůstu informačního objemu. Konektivistické činnosti tak zahrnují zejména (Tracey, 2009):

- externí kanály novinek (RSS), blogy, wiki moduly a diskusní fóra,

- sociální a profesní sítě - Facebook, Twitter apod.,

- informační rozcestníky, databáze externích odkazů.

Zajímavou se tak stává oblast zaměřená na zkoumání souvislostí mezi nástroji a postupy pro budování vlastních učebních sítí edukanta, vycházejících z principu konektivismu (srov. Siemens, 2005, Downes, 2012) a mezi internalizací základní vědomostní struktury na základě zapojení poznávacího procesu žáka či studenta, který je podporován moderními informačními a komunikačními technologiemi. Tyto poznávací (kognitivní) procesy lze vymezit slovy R. L. Atkinsonové jako: „duševní procesy vnímání, kódování informací a jejich uchovávání, zpracováváni informací, jejichž prostřednictvím jedinec ziskává informace, plánuje a řěsi problémy“ (Atkinson, 2003, s. 693). V tomto pojetí tedy kognitivní procesy vyjadřují procesuálnost lidského poznávání, kdy související kognitivní funkce určují, že se tento proces skládá z dílčích složek nebo lépe procesů. Tyto funkce a jejich složky je možné vymezit jako: „všechny myšlenkové procesy, které nám umožňují rozpoznávat, pamatovat si, učit se a prizpůsobovat se neustále se měnicim podminkám prostředí. Dále sem zahrnujeme vyšši kognitivní tzv. exekutivni funkce - schopnost řešit problémy, plánovat, organizovat, náhled a úsudek... " (Sternberk, 1990). Technologie jsou v tomto př́padě zastoupeny především sociálními sítěmi a nástroji pro kolaborativní učení ve smyslu ,interaktivní spolupráce ve skupině učicich se“ (Beckman, 1990).

V této souvislosti se tedy nabízí celá řada otázek zaměřených na skutečnost, do jaké míry je ovlivněn poznávací proces žáka či studenta moderními informačními a komunikačními nástroji a naopak, jak tyto technologie žáci a studenti využívají k budování vlastních učebních sítí a pro internalizaci své vědomostní struktury. Jisté vodítko $\mathrm{k}$ jejich zodpovězení nabízí další část textu, která je zaměřena na problematiku 
vlivu stylů a strategií učení, jakožto jednoho z významných determinantů ovlivňujících úroveň učení a využití e-learningu.

\section{Styly a strategie učení v e-learningu}

Použitá teorie učení může být také spojována s podporou různých stylů učení jedince. I když je styl učení vysoce individuální záležitostí každého studenta, e-learning by měl nabízet co nejširší možnosti uplatnění individuálních stylů učení a to na základě aktuální úrovně poznání.

„Styly učeni jsou tedy subjektivni projevy individuality člověka $v$ různých situacích učení. Jde tedy o transsituační projevy, predstavujicí metakognitivni potenciál člověka. Jsou to postupy při učení, které jedinec v daném období preferuje. Postupy svébytné svou orientovaností, motivovaností, strukturou, posloupností, svou hloubkou, elaborovaností, flexibilitou. Vyvijejí se z vrozeného základu (tj. z kognitivních stylio), ale obohacuji se a proměňuji během jedincova života jak zámérně, tak bezděčně “ (Sak \& Mareš, 2007).

Styly učení mají charakter metastrategie, která seskupuje svébytné učební strategie, učební taktiky a učební operace. Monitoruje je, vyhodnocuje, orientuje určitým směrem. Reguluje je s ohledem na podmínky učení, vlastní průběh učení, dosahované výsledky učení a s ohledem na sociální kontext učení. Styly učení vedou jedince k učebním výsledkům určitého typu, ale znesnadňují dosažení výsledků jiných (často lepších). Člověk si své styly učení zpravidla neuvědomuje, systematicky je neanalyzuje, promyšleně je nezlepšuje. Svému nositeli se styly učení jeví jako postupy samožrejmé, běžné, navyklé, jemu vyhovující, v některých př́ípadech je chápe jako postupy pro něj optimální (Mareš, 1998). V rámci multimediální formy e-learningu (viz tabulka číslo 1) bývá rozlišováno několik stylů a druhů učení, které mohou studenti při studium využívat, pokud jim to struktura a obsah použitého elektronického studijního materiálu či prostředí umožní:

- podmiňování - nejjednodušší forma učení běžná u zviřat, dětí a v určité míře i u dospělých,

- $\quad$ pojmové učení - učení poznatkům - osvojování znalostí,

- učení intelektových činností - rozvíjí se myšlenkové procesy, intelektové dovednosti a schopnosti k řešení složitých problémů.

Tyto styly a druhy učení jsou založeny na identifikaci určitých pojmů či situací a manipulace s nimi. Proto je možné tyto styly a druhy učení využívat u elektronických studijních materiálů, které obsahují informace lineárně uspořádané a nezáleží tak tolik na tom, jakou cestou se stimul ke studentovi dostane.

Naproti tomu styly a druhy učení, které mohou využít možností výpočetní techniky, a tudíž jeho hypermediálního či „konektivistického“ rozměru, jsou založeny především na vícepercepčním vnímání a tomu také odpovídá dosah jejich prezentačních možností. V rámci multimediálního či hypermediálního e-learningu studenti při studiu efektivněji využívat, nebot' charakter a možnosti elektronických studijních omateriálů a studijních „učebních“ prostředí jim toto umožní:

habituace - navykání si na okolní jevy (v pojetí hypermediálního vzdělávání odpovídá možnostem virtuální reality), 
- $\quad$ senzomotorické učení (smyslově pohybové) - rozvíjí se senzomotorické schopnosti a procesy názorného poznávání (v pojetí hypermediálního vzdělávání odpovídá možnostem interaktivních simulací),

- $\quad$ sociální učení - učení sociální komunikaci, interakci a percepci, osvojují se sociální dovednosti, formují motivy a charakter. Ve stručnosti lze definovat jako: "učení žít mezi lidmi" ( $\mathrm{v}$ pojetí hypermediálního vzdělávání odpovídá možnostem on-line forem komunikace) (Sak \& Mareš, 2007).

Zde můžeme demonstrovat souvislost učebních stylů $\mathrm{s}$ pojmy využívanými $\mathrm{v}$ rámci e-learningu na jednom konkrétním př́kladu. V souvislosti s využitím multimediálních prvků (text, grafika, zvuk či video) je možné vypozorovat dopad na základní čtyři typy studentů a to ty, kteří preferují vizuální neverbální (zrakově-obrazový), auditivní (sluchový), vizuálně verbální (zrakově-slovní) či kinestetický (pohybový) styl učení (srov. Mareš, 1998, Klement \& Dostál, 2014). Vizuálně orientovaní studenti (vizuálně verbální a neverbální) častěji preferují statickou, ale i dynamickou obrazovou informaci založenou na interaktivních animacích, videosekvencích či na práci s hypertextem. Auditivně orientovaní studenti pak spiše preferují obraz či text doprovázený zvukem. Kinestetičtí, psychomotoricky orientovaní studenti, při studium upřednostňují manipulaci či řešení konkrétních problémů (Klement \& Dostál, 2014). Možnosti práce s objekty, generovanými či ř́zenými výpočetní technikou, jim $\mathrm{v}$ tomto mohou vycházet vstrí́c různými poskytovanými technikami, jako je uchop a přenes (Drag and Drop) apod. (Turek, 2005). Takoví studenti tedy častěji preferují proces učení vlastní činností Learning by Doing. (Pavlíček, 2003, s. 55).

V pracích některých autorů, jako např. Lewis a Orton (Sak \& Mareš, 2007), objevují názory označující různé styly za mýtus, jenž je třeba zbavit falešného pozlátka, a kladou větši důraz na pojem „strategie učení“ (Mareš, 1998). Pojem strategie učení je možné vymezit jako „promyšlené a plánovité taktiky, techniky, způsoby a postupy učení se, specifické metody uspořádávání pojmů do systémových kontextů a souvislostí a průběžná autostimulace k učení“ (Kohoutek, 2008).

$Z$ hlediska e-learningu je možné přijmout $i$ jiné rozdělení stylů učení (modelů či architektur), které uvádí Merrill (2002). V tabulce 2 jsou porovnány styly učení, které jsou prǐřazeny k výukovým strategiím odpovídajícím př́islušné teorii učení. Seřazení je záměrně provedeno tak, že styly učení uvedené v tabulce odpovídaly i jiným klasifikacím tak, aby co nejlépe znázorňovaly učení od jednoduchých postupů po složité, od učení smyslového po vysoce intelektové. Celá situace je záměrně zjednodušena tak, aby ukázala těžiště jednotlivých strategií učení.

\begin{tabular}{cccc}
\hline \multicolumn{4}{c}{ Strategie výuky využitelná v př́slušné teorii učení } \\
\hline Styly učení & Programované učení & Kognitivní teorie & Konstruktivní učení \\
\hline Receptivní & $\mathbf{X}$ & & \\
\hline Direktivní & $\mathbf{X}$ & $\mathbf{X}$ & \\
\hline Rézené objevování & & $\mathbf{X}$ & $\mathbf{X}$ \\
\hline Zkoumání & & & \\
\hline
\end{tabular}

Tab. č. 2: Matice strategií učení a stylů podle J. Pavlička (2003) 
Uvedenou tabulku je potom možné interpretovat tak, že korespondenční forma vzdělávání vycházející z teorie programovaného učení lépe odpovídá nižšímu zapojení intelektuálních procesů, hypermediální forma vzdělávání postavená na učení podle konstruktivistického př́stupu pak nejvyšší úrovni učení. Kognitivistické postupy uplatněné v multimediální formě vzdělávání se nacházejí uprostřed.

\section{Závěr}

„Morální zastaráni““ korespondenčních či multimediálních forem vzdělávání je výsledkem nejen mohutné exploze informačních a komunikačních technologií, ale je také logickým vyústěním postupného přibližování těchto technologií potřebám pedagogické teorie a praxe. Toto přibližování je možné identifikovat $\mathrm{v}$ oblasti vytváření „učebních prostředí “ či softwarových produktů, které dnes umožňují aplikaci některých metod konstruktivistické pedagogiky a kognitivní psychologie (Klement, Dostál, 2014).

$\mathrm{Na}$ uvedených skutečností je tedy možné problematiku částečně zobecnit a to do podoby některých rozvojových trendů, které je možné v současné době vypozorovat v oblasti rozvoje e-learningu. Tyto rozvojové trendy jsou charakteristické cílevědomou aplikací některých prvků konstruktivistických teorií, například v podobě rozšiřování strategií učení či v podobě efektivnějšího dosahování stanovených výukových cílů, a to nejen v kognitivní, ale i psychomotorické a afektivní oblasti.

Jedním z těchto parciálních trendů je snaha o uplatňování širšího spektra stylů učení. Tradiční pojetí korespondenčních či multimediálních forem vzdělávání vycházející především $\mathrm{z}$ behaviorální teorie programovaného učení, bylo $\mathrm{v}$ pozdějších fázích doplněno kognitivní teorií učení. $\mathrm{V}$ poslední době byla i tato teorie postupně doplňována konstruktivistickou či konektivistickou teorií učení. Jelikož ale jedním z hlavních prezentačních prvků učiva v e-learningu je stále ještě elektronický studijní materiál, původně $\mathrm{v}$ tištěné a dnes $\mathrm{v}$ hypertextové či multimediální podobě, bylo možné $\mathrm{v}$ rámci jejich využití možné dosahovat převážně jistých úrovní učení. Vyspělejší technologie, ale umožñují častěji využít postupů a způsobů učení, které lépe vyhovují osobnostním charakteristikám studentům, a proto je pro ně studium může být nejen efektivnějšś, ale také prínosnější.

Trend efektivnějšího dosahování výukových cílů je odrazem skutečnosti, že realizace korespondenčních či multimediálních forem vzdělávání byla založena $z$ velké části na přenosových médiích, která ne vždy umožňovala využívat některé efektivní prvky uplatnění zásady názornosti, ale někdy také zvyšovala obtížnost dosahování afektivních či psychomotorických cílů vzdělávání. V současné době, s využitím možnosti simulace či virtualizace, je možné velmi efektivním způsobem dosahovat nejen kognitivních vzdělávacích cílů, ale také afektivních a psychomotorických. Využití těchto moderních technologií ale předpokládá plně elektronizovaný systém studia, kdy je distanční vzdělávání realizováno formou e-learningu, a existuje tedy hypermediální obsah zakomponovaný v LMS či LCMS systému.

\section{Literatura}

Anderson, J., McCormick, R. (2005). A common framework for e-learning quality education. European schoolnet.

Atkinson, R. L. (2003). Psychologie. Praha: Portál.

Barešová, A. (2003). E-learning ve vzděláváni dospělých. Praha: VOX. 
Bates, A., Poole, G. (2003). Effective Teaching with Technology in Higher Education. San Francisco: Jossey-Bass/John Wiley.

Beckman, M. (1990). Collaborative Learning: Preparation for the Workplace and Democracy? College.

Bennett, S., Maton, K. \& Kervin, L. (2008). The 'digital natives' debate: A critical review of the evidence. British Journal of Educational Technology 39(5). s. 12-31. Clark, R. C. - Mayer, R. E. (2011). E-Learning and the Science of Instruction: Proven Guidelines for Consumers and Designers of Multimedia Learning. San Francisco, CA: Pfeiffer.

Downes, S. (2012). Connectivism and Connective Knowledge: Essays on meaning and learning networks [online]. Toronto: National Research Council Canada.

Eger, L. (2004). Evaluace e-learningu se zaměřením na pedagogickou stránku. In $E$ learning - př́padová studie z projektu Comenius. Plzeň: ZČU Plzeň.

Eom, S. B. \& Arbaugh, J. B. (2011). Student Satisfaction and Learning Outcomes in ELearning: An Introduction to Empirical Research. Hershey PA: Information Science Reference.

Hunt, M. (2000). Dějiny psychologie. Praha: Portál.

liyoshi, T. \& Vijay, M. S. (2008). Opening Up Education: The Collective Advancement of Education through Open Technology, Open Content, and Open Knowledge. Chicago, M.I.T. Press.

Joo, Y. J., Lim, K. Y. \& Kim, E. K. (2011). Online university students' satisfaction and persistence: Examining perceived level of presence, usefulness and ease of use as predictors in a structural model. Computers \& Education 57(2).

Klement, M. et al. (2012). E-learning: elektronické studijní opory a jejich hodnocení. Olomouc: Agentura Gevak.

Klement, M. \& Dostál, J. (2014) Styly učení dle klasifikace vark a možnosti jejich využití ve vysokoškolském vzdělávání realizovaném formou e-learningu. Journal of Technology and Information Education. Olomouc - EU, Univerzita Palackého, 6(2), s. 58-67. Dostupné na: <http://www.jtie.upol.cz/cz/magno/jti/2014/mn2.php>.

Kluge, S. \& Riley, L. (2008). Teaching in Virtual Worlds: Opportunities and Challenges. In Issues in Informing Science and Information Technology 4(5), s. 127-135.

Kohoutek, R. (2008). Dějiny psychologie pro pedagogy. Brno: Masarykova univerzita. Kop, R. (2011). The challenges to connectivist learning on open online networks: Learning experiences during a massive open online course. International Review of Research in Open and Distance Learning, 12(3). Athabasca, AU Press.

Kopecký, K. (2006). E-learning (nejen) pro pedagogy. Olomouc: Hanex. Li, Y. \& Powell, S. (2013). MOOCs and Open Education: Implications for Higher Education White Paper. University of Bolton: CETIS.

Lowenthal, P. R. \& Wilson, B. (2009). A description and typology of the online learning landscape. In: M. Simonson (Ed.), 32nd Annual proceedings: Selected research and development papers presented at the annual convention of the Association for Educational Communications and Technology. Washington D. C.: Association for Educational Communications and Technology.

Lupač, P. (2011). Mýty (a realita) digitální generace [online]. Lupa [cit. 2016-01-10]. Dostupné na: http://www.lupa.cz/clanky/myty-a-realita-digitalni-generace/ Mareš, J. (1998). Styly učeni žákio a studentů. Praha: Portál. 
Matt, S. \& Fernandez, L. (2013). Before MOOCs, Colleges of the Air. Chronicle of Higher Education, 40(2). Washington D.C.

Mauthe, A. \& Thomas, P. (2004). Professional Content Management Systems: Handling Digital Media Assets. John Wiley \& Sons.

Merrill, M. D. (2002). Instructional Strategies and Learning Styles: Which Takes

Precedence? Issues in Instructional Design and Technology. Merrill Prentice Hall. s. 99 106.

Moncton, S. D. (2007). What Connectivism Is. Half an Hour 7(3), [cit. 2016-02-03].

Dostupné na: http://halfanhour.blogspot.com/2007/02/what-connectivism-is.html

Oblinger, D. \& Oblinger, J. (2005). Is It Age or IT: First Steps Toward Understanding

the Net Generation. Educating the Net Generation [on-line]. Educause, c2005 [cit. 201603-011]. Dostupné na:

http://www.educause.edu/Resources/EducatingtheNetGeneration/IsItAgeorITFirstSt Palfrey, J., \& Glasser, U. (2008). Born Digital: Understanding the First Generation of Digital Natives. Oxford, Oxford Press.

Parr, Ch. (2012). "Mooc creators criticise courses' lack of creativity". Times Higher Education, 10(4). London, TSL Education.

Paulsen, M. F. (2003). Online Education and Learning Management Systems - Global Elearning in a Scandinavian Perspective. Oslo: NKI Forlaget.

Pavlíček, J. (2003). Základy e-didaktiky pro e-tutory: studijni materiály pro distanční kurz Dovednosti e-tutora. Ostrava: Ostravská univerzita.

Petty, G. (1996). Moderní vyučování. Praha: Portál.

Piaget, J. (1955). The Child's Construction of Reality. London: Routledge and Kegan

Paul.

Piaget, J. (1999). Psychologie inteligence. Praha: Portál.

Plháková, A. (2006). Dějiny psychologie. Praha: Grada.

Prensky, M. (2001). Digital Natives, Digital Immigrants: Do They Really Think

Differently? [online]. On the Horizon 9(5), [cit. 2016-01-03]. s. 7-11. Dostupné na:

http://www.marcprensky.com/writing/Prensky\%20-

\%20Digital\%20Natives, \%20Digital\%20Immigrants\%20-\%20Part2.pdf

Prensky, M. (2009). Homo Sapiens Digital: From Digital Immigrants and Digital Natives to Digital Wisdom. Innovate 5(3), [cit. 2016-01-03]. Dostupné na:

http://www.innovateonline.info/pdf/vol5_issue3/H._Sapiens_Digital_From_Digital_Imm igrants_and_Digital_Natives_to_Digital_Wisdom.pdf

Průcha, J. \& Míka, J. (2000). Distančni studium v otázkách. Praha: NCDV.

Ramanau, R. \& Hosein, A. - Jones, Ch. (2010). Learning and living technologies:

a longitudinal study of first-year students' expectations and experiences in the use of ICT.

In 7th International Conference on Networked Learning. Aalborg: Open University

Business School, s. $627-634$.

Sak, P. \& Mareš, J. (2007). Člověk a vzdělání v informační společnosti. Praha: Portál.

Siemens, G. (2005). Connectivism: A Learning Theory for the Digital Age. International

Journal of Instructional Technology and Distance Learning 2(1), [cit. 2016-01-01].

Dostupné na: http://www.itdl.org/Journal/Jan_05/article01.htm.

Smith, D. S. \& Caruso, J., B. (2010). The ECAR study of undergraduate students and information technology. EDUCAUSE. Dostupné na:

http://net.educause.edu/ir/library/pdf/ ers1006/rs/ers 1006w.pdf. 
Šedá, J. (2010). E-learning - tvorba studijnich opor. Praha: Vysoká škola ekonomická. Šimonová, I. (2010). Styly učení v aplikacích eLearningu. Hradec Králové: M\&V Hradec Králové.

Tapscott, D. (1998). Growing Up Digital: The Rise of the Net Generation. New York: McGraw-Hill.

Tracey, R. (2009). Instructivism, Constructivism or Connectivism? Learning in the Corporate Sector, [cit. 2014-03-05]. Dostupné na:

http://ryan2point0.wordpress.com/2009/03/17/instructivismconstructivism-orconnectivism/

Turek, I. (2005). Inovácie v didaktike. Bratislava: Metodicko-pedagogické centrum. Veen, W. \& Vrakking, B. (2006). Homo Zappiens. Growing Up In A Digital Age. London, Network Continnum Education.

Vygotskij, L. S. (1962). Thought and Language. Cambridge, Mass.: The M.I.T. Press. Zounek, J. \& Sudický, P. (2012). E-learning učeni se s online technologiemi. Praha, Wolters Kluwer.

Zounek, J. (2009). E-learning - jedna z podob učení v moderní společnosti. Brno: Masarykova univerzita. 